\title{
ベクトル視/スカラー視の指標を用いた町屋筋の空間評価方法の検討 METHOD ON SPACIAL EVALUATION OF TOWNSCAPE IN A TRADITIONAL STREET BY USE OF A NEW CONCEPT OF VECTOR VISION/SCALAR VISION
}

\author{
鵜 飼 昭 年*, 堀越哲 美** \\ Akitoshi UKAI and Tetsumi HORIKOSHI
}

\begin{abstract}
The unity and continuity of the townscape have been lost up to date on the streets in local cities. The objective of this paper is to propose indices on evaluating those type of townscape and to confirm those application to a real townscape. Indices, scalar and vector vision indices, based on the concept of the scalar and vector illuminances to indicate diffuse and directional effects were derived. Each vision index is defined as the solid angle projection factor of content elements in the street. Chikara-machi-street which consisted of mixed landscape of modern and traditional buildings was selected to examine the indices and to evaluate the characteristics of the street. The ratio of vector to scalar vision was also defined as a combined index. It was confirmed that the scalar vision index corresponded to unconscious vision and the vector vision index did to conscious grazing, respectively.
\end{abstract}

Keywords : pedestrian space, solid angle projection factor, visual perception, scalar vision index, vector vision index, ratio of vector of scalar vision

歩行街路空間，立体角投射率，視知覚，スカラー視，ベクトル視，ベクトル/スカラー視比

\section{1. はじめに}

都市部の居住地区は、交通網の拡充のための拡幅整備等により、 街路は通過道路としての機能に特化し、経済活動を最優先するあま り、高層マンションの建設による乱開発が進んだことで、街路が本 来持つ「生活空間としての質」を失いつつあると考えられる。もと もと、歴史的景観やまちなみを含む、良好な歩行空間を保持する豊 かな地域コミュニティを形成していた地区であっても、無計画な開 発や中断による空き地化や駐車場化は、街路が一定のアイデンティ ティを維持するために必要な連続性を衰失させていると考えられる。 歴史的景観保存地区やまちなみ保存地区などで、環境要素を記号 論的に把握し、その保存や再生の重要性を共有することは大切なこ とであるが、地方都市の町家筋においては、街区の統一性や歴史性 が崩壊しつつある現実があり、さまざまな状沉が混在して、従来の 景観評価方法だけで把握することが困難になってきている。

そこで本論文は、人が「見る」ことにおいて視野全体を見る「な がめ」とその中であるものに注視して見る「まなざし」を考え、こ れに基づく、新しい指標によって、まちなみを表現し、町家筋景観 の視環境評価を行うことを目的し、得られた結果を、継続したまち なみ変化の検討資料として整備しょうとするものである。

\section{2. 新たな指標の提示}

2. 1 スカラー視、ベクトル視、ベクトル/スカラー視比 町屋筋を歩行し景観を認識する際、環境全体からの景観（情報）
を無意識的に認識する、あるいはどこを限定することなく見る、見 回すという「ながめ」と指向性をもって見ることや対象を限定して 見る「まなざし」というふたつの状況行為があると考え、その概念 が同時に存在すると考えた。それはすなわち、人間は風景をものか らの反射光としてとらえるわけで、人間の眼球に光として入ること と対応づけられると考えられる。あるものやことに着目、注目して 視線を向ける、落と寸という、いわばその光が指向性をもって入っ てくるか、拡散的に入ってくるかということに帰着すると考えた。 その入力される光の様態について、明るさを示寸指標として全方向 から指向性のある光も含み、拡散的に入る光の総量にあたるスカラ 一照度と光の指向性を示すべクトル照度の概念がある。

そこで、光の指向性や拡散性を表現できる光環境指標のベクトル 照度、スカラー照度、ベクトル/スカラー比の考え方 ${ }^{1)}$ に着目し、 援用することとした。スカラー照度とはある点に全方向から入射す る光の総量をいい、ベクトル照度とは、ある点における正反対の向 きの微小面照度差が最大のときの照度差と方向、さらにベクトル／ スカラー比とは、ある点のベクトル照度絶対值をスカラー照度で除 した值をいう。それを以下のように視知覚に援用し、新たな指標、 スカラー視、ベクトル視、ベクトル/スカラー視比を提案する。

スカラー視は 歩行者に視知覚として入射してくる均一的で無意 識的な「ながめ」を示すものと考え、ベクトル視はスカラー視から 連続的に想起される意識的指向性のある「まなざし」を示すものと 考える。ベクトル/スカラー視比は、これらを連成指標として見る
$*$ 名古屋工業大学大学院工学研究科

博士後期課程 $\cdot$ 修士 (工学)

** 名古屋工業大学大学院工学研究科 教授. 工博
Graduate Student, Nagoya Institute of Technology, M. Eng.

Prof., Nagoya Institute of Technology, Dr. Eng. 
とき、人が特に関心を抱き注目する要素として抽出される。

景観の認識を光の情報としてとらえるとすると、この光の状態の 表現に相似寸ると考えた。すなわちスカラー照度に倣ったスカラー 視は「ながめ」にあたり、ベクトル照度に倣ったベクトル視は「ま なざし」にあたるものとして、指標を設定したものである。

ここで、スカラー視、ベクトル視、ベクトル/スカラー視比の定義 を示す。まちの環境要素 $a_{\mathrm{i}}$ について、進行方向に鉛直な面上の $\mathrm{A} の$ 半球面に投影された $a_{\mathrm{i}}^{\prime}$ により半球底面に投射された $a_{\mathrm{i}}$ にによる立 体角投射率を $a_{\mathrm{i}} \varphi_{\mathrm{A}}$ とする。半球の底面に対する鉛直方向（図では上 方）が進行方向となる。この様子を図 1 に示す。

同様に後方の $\mathrm{B}$ の半球面への投影による立体角投射率を $a_{\mathrm{i}} \varphi_{\mathrm{B}}$ 、両 側面の C, D 一の投影による立体角投射率を、それぞれ $a_{\mathrm{i}} \varphi_{\mathrm{C}} 、 a_{\mathrm{i}} \varphi_{\mathrm{D}}$ と表すとき、図 2 と図 3 に示される方向性を考慮して、スカラー視 とベクトル視等を以下に定義する。

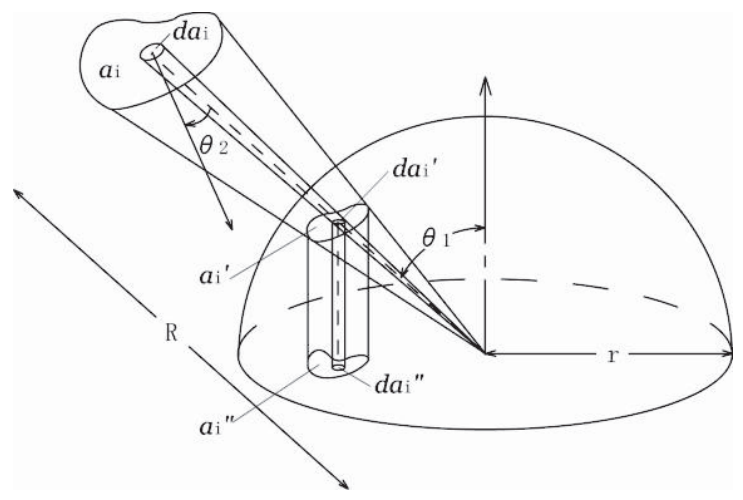

立体角投射率： $\boldsymbol{\varphi}=\boldsymbol{a}_{\mathrm{i}} " / \boldsymbol{\pi} \mathrm{r}^{2}$ である。

図 1 立体角投射率の概念

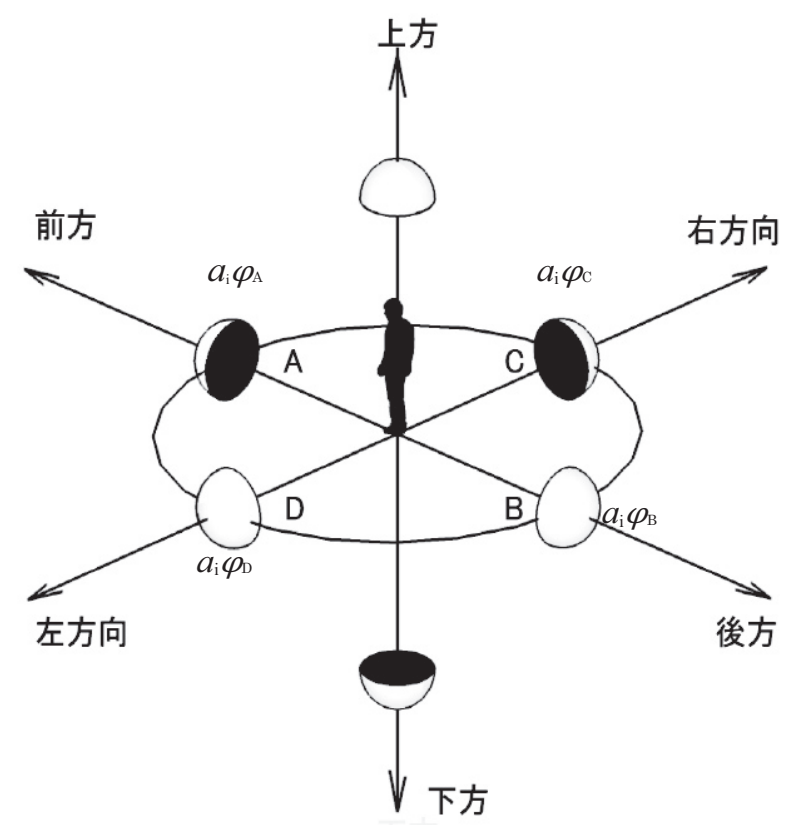

図 2 各方向に対する立体角投射率の測定

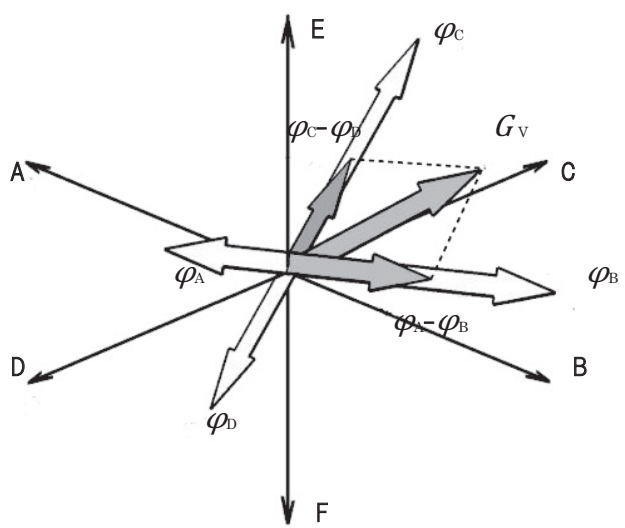

図 3 ベクトル視の概念

$a_{i}$ に対するスカラー視 $G \mathrm{~s}$

$G \mathrm{~s}=\frac{1}{n} \sum_{\mathrm{J}=1}^{n} a_{i} \varphi_{\mathrm{J}} \quad(\mathrm{n}=4$ とする $: \mathrm{A}, \mathrm{B}, \mathrm{C}, \mathrm{D})$

$a_{i}$ に対するベクトル視 $G \mathrm{v}$

$G \mathrm{~V}=\sqrt{\left(\boldsymbol{a}_{i} \varphi_{\mathrm{A}}-\boldsymbol{a}_{i} \varphi_{\mathrm{B}}\right)^{2}+\left(\boldsymbol{a}_{i} \varphi_{\mathrm{c}}-\boldsymbol{a}_{\mathrm{i}} \varphi_{\mathrm{b}}\right)^{2}}$

$\boldsymbol{a}_{i}$ に対するベクトル/スカラー視比 $G \mathrm{vs}$

$G$ vs $=G_{\text {v }} / G$ s

\section{2 先行研究との相違点}

大野ら ${ }^{2)}$ は人の視知覚を焦点視と環境視に分類した上で、等立体 角射影レンズを用いた定量的な測定方法を提示し、環境の見張りと して広い範囲から無意識的に情報を得る環境視と特定の変化が起き た場合の密な情報を得るための焦点視の役割を区別して論じている。 この研究は焦点視と環境視が同時に存在する想定ではないことと立 体角比を用いている点で、本論文と相違する。

若山ら ${ }^{3)}$ はメッシュグリッドを用いたファサード研究を行ってい る。これは正面からの撮影であるため、本論文が提示する無意識的 に街路空間を歩行する際の指標とは区別される。

益岡ら ${ }^{4)}$ はシークエンス研究として、進行方向を撮影したうえで 心理量変化について論じている。川合ら ${ }^{5)}$ は代替視野画像を用いて 連続的に変化する「シークェンス空間」における各街路の「注視要 素エントロピー」を算出し、注視を促す「空間構成要素」について 論じている。また、永瀬ら ${ }^{6)}$ は人が街路の景観を認識する時、眼球 や回頭行為により得られたシーンの総体によって心象を形成すると 述べている。これらは、時間推移や見る行為として既にアプローチ しており、天空、後方、側方も含めて同時に知覚する立場をとる本 論文とは異なる。

黄ら ${ }^{7)}$ は「可視空間量」の概念を用い、空間の圧迫感と開放感に ついて論じているが、本論文が目指寸評価法とは異なる。

守山ら ${ }^{8)}$ は京都の街並み景観を対象として立面景観を「記号学的」 に抽出し「関係性のデザイン」について論じている。これは京都の 伝統的景観要素が密実に連続している対象を正面から分析している 点で従来とは異なる点が評価されるが本論文とは区別される。

速水ら ${ }^{9)}$ は「街路シークエンス景観」の定量記述手法として「ゆ らぎ」を用いている。また、瀬田ら ${ }^{10)}$ は、ゆらぎ理論を用いて街 
路景観の乱雑性、整然性、魅力度について論じている。船越ら ${ }^{11)}$ は参道空間中の分節点における天空率、面積などの物理量変化によ って「シークエンス空間」を記述している。これは連続した想定で なく、分節点をとらえている点と、全体の把握とある要素の把握を 同時に行う本論文とは異なる。

竹内ら ${ }^{12)}$ はV V R R 画像中から抽出される景観構成要素の面積比 を測定し印象評価との関係を論じている。辻ら ${ }^{13)}$ は 2 次元の地図 データから建物と空隙の二值化画像としたものにフーリエ変換を適 応して空間周波数を導き空間的特徵の分析を試みている。これらは 連続した景観をとらえる手法として新しく提案されているが本論文 の方法とは異なる。

\section{3. 研究方法}

\section{1 対象地域}

名古屋の中心部に位置する、東区白壁地区、主税町地区、橦木町 地区界隈は、特徵としては、名古屋城築城時に成立した碁盤目状の 街区割（図 4）の上に、明治、大正、昭和と住み手を変えながら、 歴史的まちなみや閑所注1) と呼ばれる路地、塀や樹木などの都市的 構成を今も残している町屋筋であり、近年では「文化のみち」と命 名され、いくつかの歴史的建造物が保存活用され、評価も高まって きている。

その反面、現状としては、図 5 に示されるように、土地の形状の 変更、空き地化と駐車場化、マンションなどの高層化によってまち なみの連続性や路地が減少し、新旧の建築が混在している。

そのため、従来の歴史的景観としての評価が難しい地域であると 考えられ、実験対象地域として選定し、本調查では、特に現代建築 や歴史的建築、町屋や閑所（図 6)、現代の建築や空き地や駐車場が 混在する主税町筋の、国道 19 号線と国道 41 号線に挟まれた範囲で 調查を行った（図 7)。

\section{2 調査の方法}

街路の南側と北側の 64 ポイントにおいて、正射影魚眼レンズを 用いて図 2 に示寸天空、進行方向、後方、両側面の 5 方向を撮影し た。撮影ポイントは歩行者が街路を認識することを目的としている ことから道路の両端とした。

この地域の特徴的な環境要素をあらかじめ抽出してあったものを 参考にして、撮影された画像を、表 1 に示寸ような 15 種類の環境要 素に分類することとした。この事例を図 8 に示す。
看板や自動車といった要素については本論では含まれていない。看 板や自動車によって遮られている環境要素に関しては追加の現地調 査において、その背後にある環境要素を採用している。

\section{3 分析の方法}

このような分類に基づき、実験対象地域の各観測点において、各 撮影方向における、15の各環境要素についての立体角投射率を SPCONV ver. 0. $6^{14)}$ を用いて求めた。これを図 9 に示す。

分析では A, B, C, D の方向に向けて写した射影すなわち水平方向に むけて一周した景観に関して論じている。上方はほとんど天空が占 め、下方は道路が占めることになる。スカラー照度でも一般的には、 球面一入射寸る場合を考えるが、上下方向を考えない場合や影響の 少ない場合には円筒面入射として取り扱う ${ }^{15)}$ 。視線は上下より、 水平に動くことが多いといわれていることによる処置である。本研 究もそれに倣い、水平 4 方向を用いることとした。

すべてのポイントにおいて 4 方向のデータが存在する。それらを 合成してそのポイントの值としている。ここでは、あるポイントで の立体角投射率を各方向について求めており、それに含まれる要素 が重複していることで、4方向のデータによって全周を表すことが 可能となる。これは 4 方向の值を求めて、球や円筒に対するスカラ 一照度を求める方法によっている ${ }^{16)}{ }^{17)}$

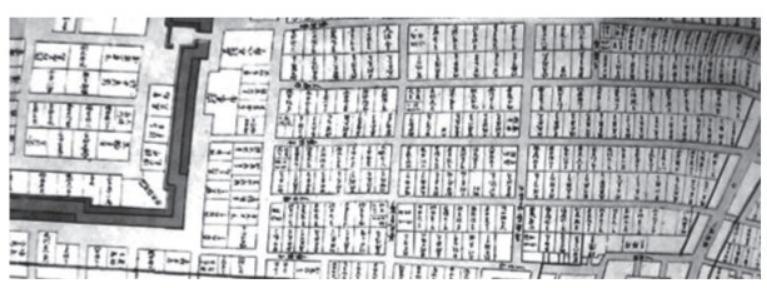

図 4 江戸時代の碁盤の目の町割 安政年間の地図
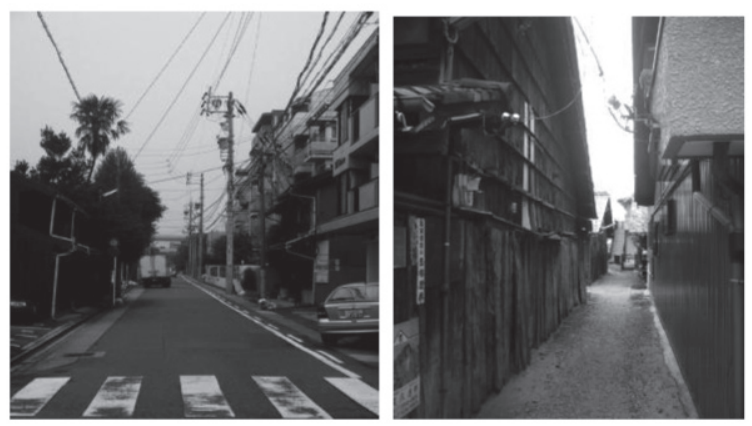

図 5 新旧の建築が混在する様子 図 6 閑所と呼ばれる路地空間

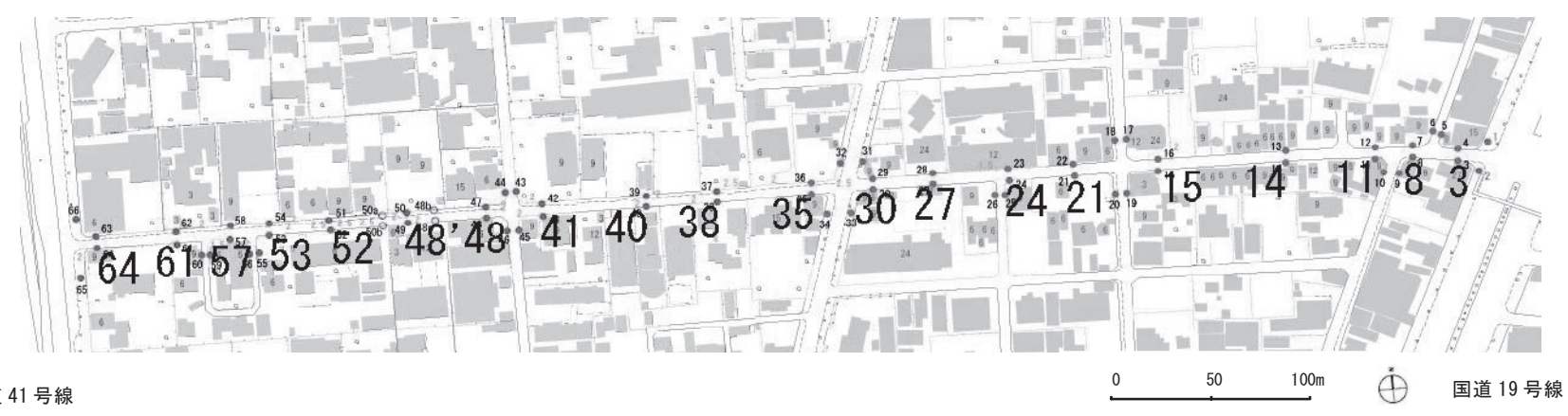

図 7 名古屋市東区主税町界隈 調查対象地域 


\begin{tabular}{|c|c|c|c|}
\hline & 要素 & 性㗨 & 内容 \\
\hline 1 & 空 & & \\
\hline 2 & 剭根 軒 & 木製 & 屋根の軒下ーで木製のもの \\
\hline 3 & 屋根 軒 & 非木製 & 屋根の軒下ーで木製てで無いりりの \\
\hline 4 & 下偓 軒 & 木製 & 下屋の軒下で木製のもの \\
\hline 5 & 穴屋軒 & 韭木製 & 下屋の軒下ーで木撆でないもの \\
\hline 6 & 開口 半透明 & 古， & $\begin{array}{l}\text { 内部空間价見えない,開口部で } \\
\text { 木製格子空や木製建具など }\end{array}$ \\
\hline 7 & 開 $\square$ 半透明 & 新しい & $\begin{array}{l}\text { 内部空間が見えない,開口部で } \\
\text { アルルシッッシなと }\end{array}$ \\
\hline 8 & 開口 透明 & & $\begin{array}{l}\text { 透明ガラスなどで内部空間が } \\
\text { 見える }\end{array}$ \\
\hline 9 & 壁面 奥八 & 木製 & $\begin{array}{l}\text { 路地に面する壁や空地に面す } \\
\text { る道路から舆まっていく票の } \\
\text { 中で木製のもの }\end{array}$ \\
\hline 10 & 壁面 奥へ & 非木製 & $\begin{array}{l}\text { 路地に面する壁や空地に面す } \\
\text { る道路から的奥まっていく要素の } \\
\text { 中でモルタけや鉄粄のもの }\end{array}$ \\
\hline 11 & 壁面 鉛直 & 木製 & $\begin{array}{l}\text { 道路に面して鉛直に立つ面的 } \\
\text { 要素のうち製のもの }\end{array}$ \\
\hline 12 & 壁面 鉛直 & 非木製 & $\begin{array}{l}\text { 道路にこ面して鉛直にこ立つ面的 } \\
\text { 要素のうちモル特のタール } \\
\text { 鉄板のもの }\end{array}$ \\
\hline 13 & 樹木 & & \\
\hline 14 & 敨地内土間 & & $\begin{array}{l}\text { 犬走りや路地における地面で } \\
\text { 道路以外の土間要素 }\end{array}$ \\
\hline & 道路 & & 敷地以外D道路部分 \\
\hline
\end{tabular}

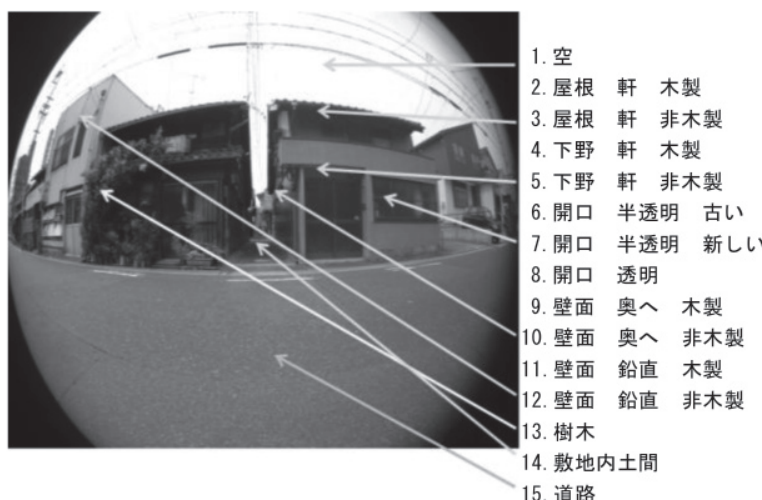

図 $8 \quad 15$ 種類の環境要素に分類

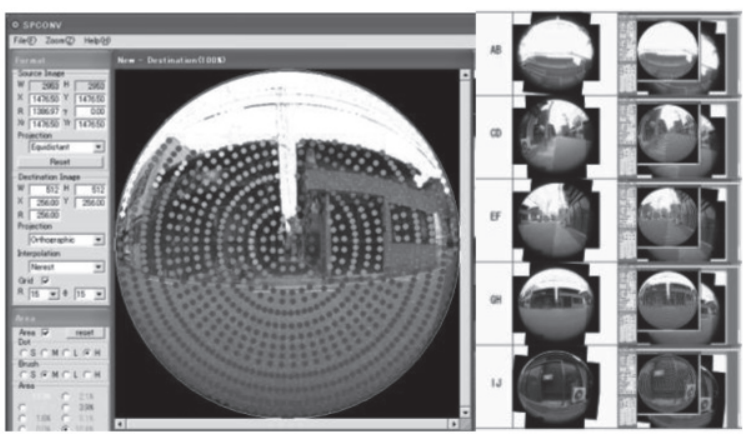

図 9 SPCONV ver. 0.6 による画像処理例

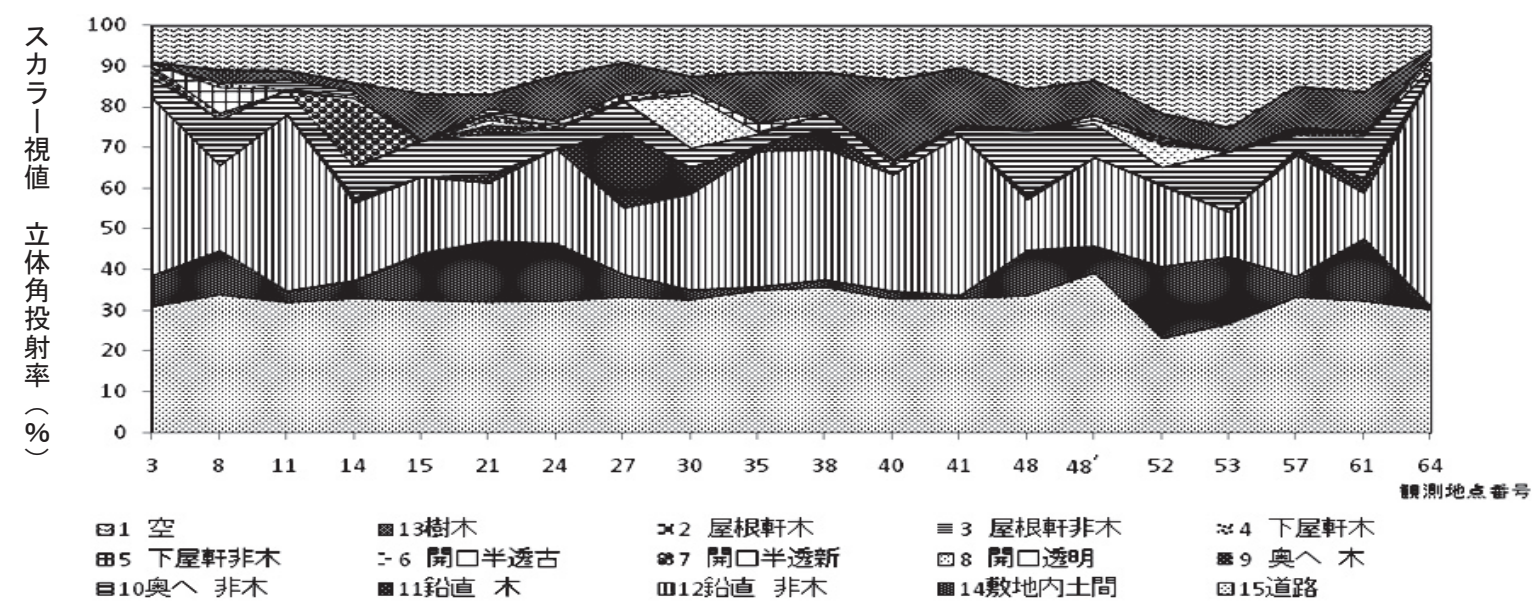

図 10 各観測点のスカラー視指標 : 各環境要素の割合を示す

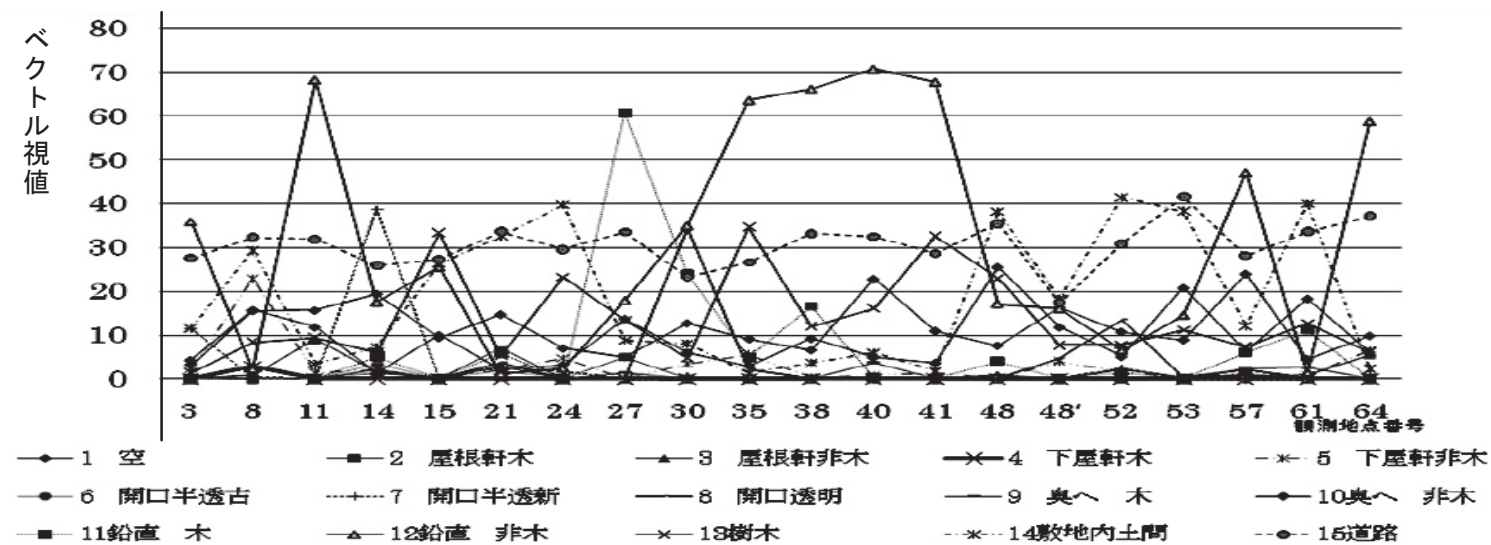

図 11 各観測点の各環境要素に対するベクトル視指標 

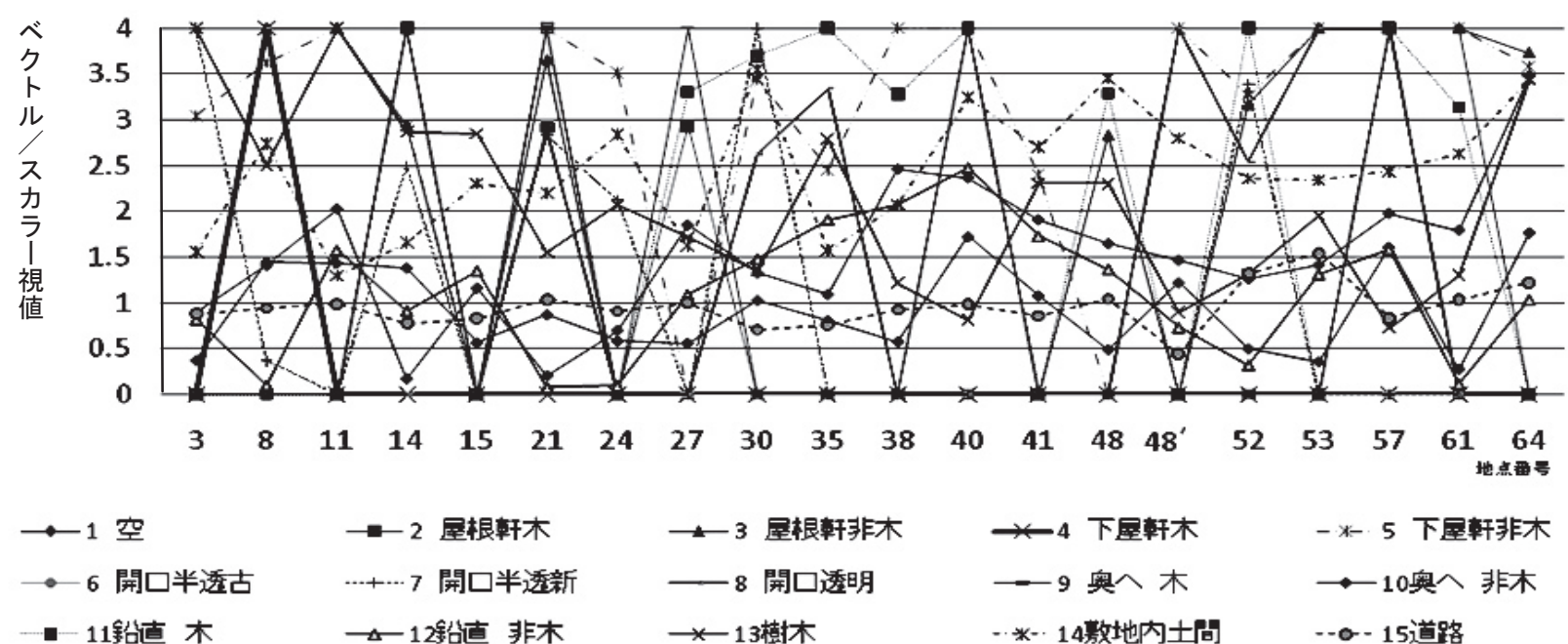

-11铅直 木

図 12 各観測点のベクトル/スカラー視比指標

\section{4. 結果}

調查結果から、式(1)より各観測点において得られた 4 方向の各 環境要素の割合の数值を環境要素ごとに全て合計し、4で除す。例 えば観測点 21 におけ「空」に関して見てみると、4方向の数值は 13. 0、24.2、10.3、19.9 であり、これらを合計すると 67.4 となり、 これを 4 で除すと 16.9 となる。これがこの観測点での「空」のスカ ラー視值となり、15 の環境要素に関して同じように計算し、各観 察地点のスカラー視值を求めグラフ化したものをスカラー視指標と して図 10 に示す。

さらに、式(2)により各観測点における 4 方向の值のうち、相反す る方向の值の差を算出し、それぞれ 2 乗して加算したものの平方根 の值がベクトル值となる。例えげ観測点 21 における「空」の前方と 後方の差は 11.2、左右の差は 9.6 となる。それぞれを 2 乗して加え た数が 217.6 となり、この平方根が 14.8 となり、この観測点におけ る「空」のベクトル視值が算出される。このように各観察地点のべ クトル視值を求め、グラフ化したものをべクトル視指標として図 11 に示す。

さらに、式(3)を用いて、ベクトル視值をスカラー視值で除した值 がベクトル/スカラー視比の值となり、求めた值をグラフ化したもの をベクトル/スカラー視比指標として図 12 に示す。

\section{5. 考察}

5.1 抽出

名古屋の町屋筋でよくみられる低層建築が並ぶ中、二つの建築に 挟まれた閑所のある観測点 21 と、近年建設された高層マンション と木造の低層建築が町屋筋を挟んで向き合う観測点 27 の特徵的な 2 つの観測点に着目寸る。この 2 つは現代と歴史的街並みが混在す る代表的な両極に位置する景観であるため、これらを抽出し検討す ることでその他の場合も類推できると考えられる。

\section{2 観測定点 21 の測定結果における考察}

木造 2 階建ての住宅と閑所を含む観測点 21 (図 13) についてみて みると、スカラー視（図 14）においては、「12. 壁面 鈆直 非木」 の割合が他の地点より比較的少ない。これは他の地点のようにマン ションなどの高い非木製の壁面が少ないことを示している。次に、
「10. 壁面 奥へ 非木」、「12. 壁面 鉛直 非木」、「14. 敷地内 土間」の 3 つ要素がほぼ均一な割合を示している。これは街路の ボリュームを示寸要素がバランスよく存在していることを示してい る。また、それぞれの值は少ないものの、「3. 屋根 軒 非木」、

「4. 下屋 軒 木」、「5. 下屋 軒 非木」、「6. 開口 半透明 古」、 「9.壁面 奥へ木」などの要素が少しずつ含まれている。これは 単調な要素のみの構成でなく多種の要素が分散して含まれている観 測点であることを示している。

ベクトル視（図 15）では「14, 敷地内土間」が顕著な值を示し、「9. 壁面 奥へ木」の要素に高い值が認められる。スカラー視では「10. 壁面 奥へ 非木」、「12. 壁面 鉛直 非木」と他のほぼ同じ值を 示していた「14. 敷地内土間」がベクトル/スカラー視比においては、

「14. 敷地内土間」が高い值を示したことは、環境においてその要素 がバランスよく平均的に存在しているだけでなく、指向性をもった 要素として抽出されていることが分かる。ベクトル/スカラー視比

（図 16）においては、「14. 敷地内土間」、「9. 壁面 奥へ木」 の要素で高い值が認められる上、「11. 壁面 鉛直 木」、「2. 屋根 軒 木」、「3. 屋根軒 非木」の值が大きく出ている。これらの要 素はスカラー視やベクトル視では目立つ值ではないがベクトル/ス カラー視比では顕著な値を示す。

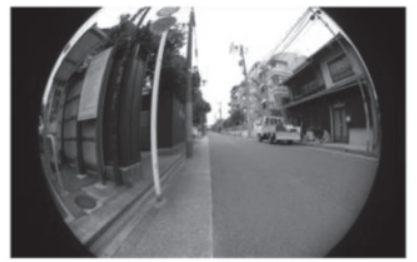

前方 $A$

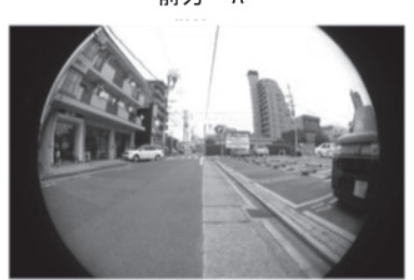

後方 B

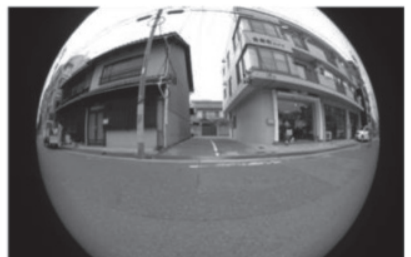

北側 C

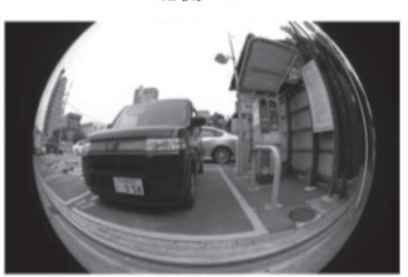

南側 D
図 13 各観測点 21 の画像 
これは空間の中で、突出したものや特徵的なるものがある景観を 量的に示すことができたものと考えられる。一方、ベクトル/スカ ラー視比が全体的に低い值の場合、様々な要素が平均的に散りばめ られている景観を示しているものと考えられる。

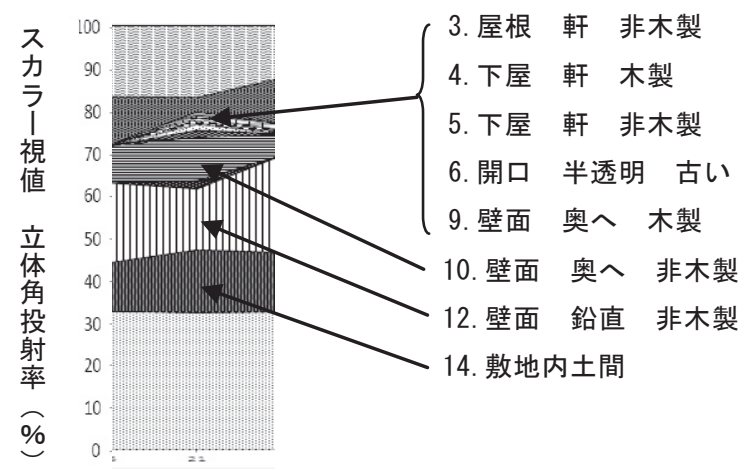

図 14 各観測点 21 のスカラー視指標

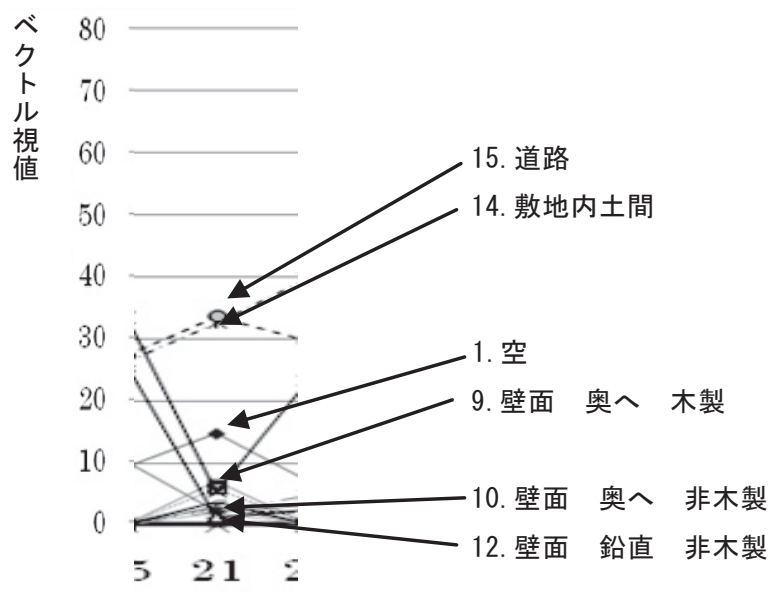

図 15 各観測点 21 のベクトル視指標

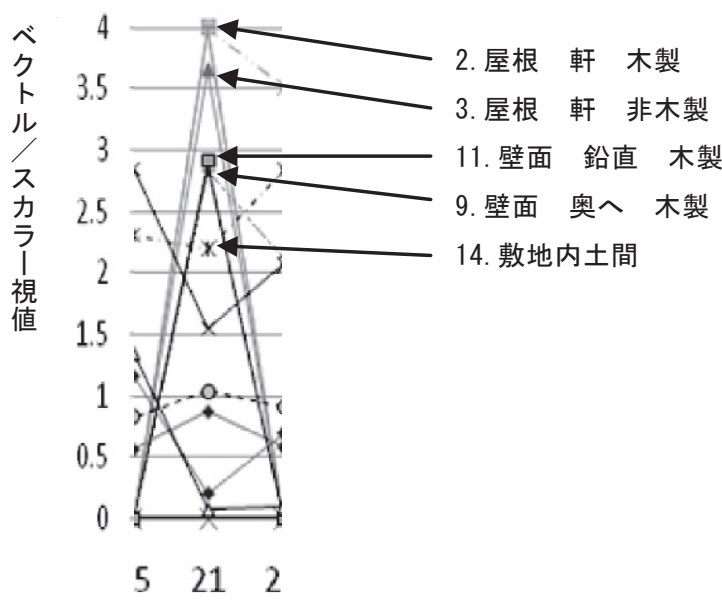

図 16 各観測点 21 のベクトル/スカラー視指標

\section{3 観測地点 27 の測定結果における考察}

次に、観測地点 27 (図 17) を見る。ここは木製の壁面でできた伝 統建築物の一部である長屋門と鉄筋コンクリート造の高層マンショ
ンが街路を挟んで向き合う場所である。

スカラー視指標 (図 18)では、「11. 壁面 鉛直 木」の要素と「12. 壁面 鉛直 非木」の要素がほぼ均等に確認される。さらに「1. 空」 が他の地点に比べると少なくなっている。これは鉛直に建つ要素が 街路を壁面のように囲っている様子を表現している。

次に、ベクトル視指標（図 19）をみると、「11. 壁面 鉛直 木 が突出した值を示している。スカラー視指標では「11. 壁面 鉛直 木」の要素と「12. 壁面 鉛直 非木」がほぼ均等だったことを考え ると、ここで、量だけでなく、指向性を持った要素が抽出されたと 考えられる。

さらに、ベクトル/スカラー視比指標（図 20）をみると、「2. 屋 根軒 木」、「9.壁面 奥へ木」、「11. 壁面 鉛直 木」が大き な值を示した。ここでも、「2. 屋根軒 木」、「9.壁面 奥へ木」 のような、他の指標では目立たなかった要素が抽出できた。このべ クトル/スカラー視比が顕著な值を示すことは、面積などが極めて 微量な要素であっても、人が認知する可能性を持った要素を抽出す ることができる指標であると考えられる。

観測地点 21 の場合と同様に、ベクトル/スカラー視比の值が高い 場合、空間の中で突出し、人が関心を持つ景観を量的に示せたと考 えられる一方、ベクトル/スカラー視比の值が低い場合は、その要 素は人の注意を引くような突出したものでなく、無意識的にその地 点の雰囲気を決定づけていると考えられる。

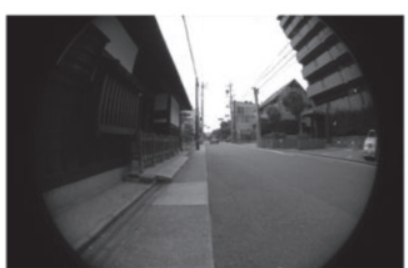

前方 $A$

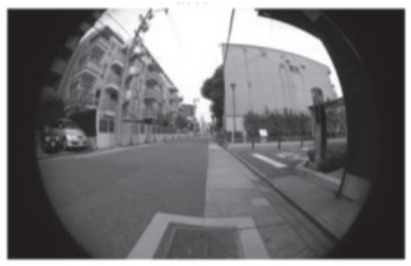

後方 $B$

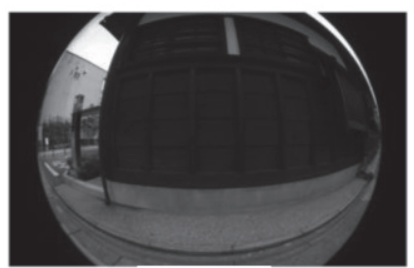

北側 C

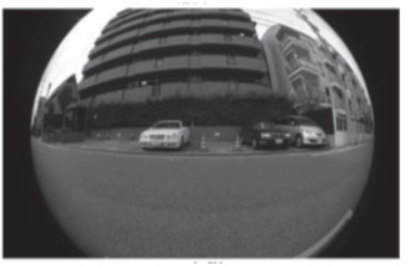

南側 D
図 17 各観測点 27 の画像

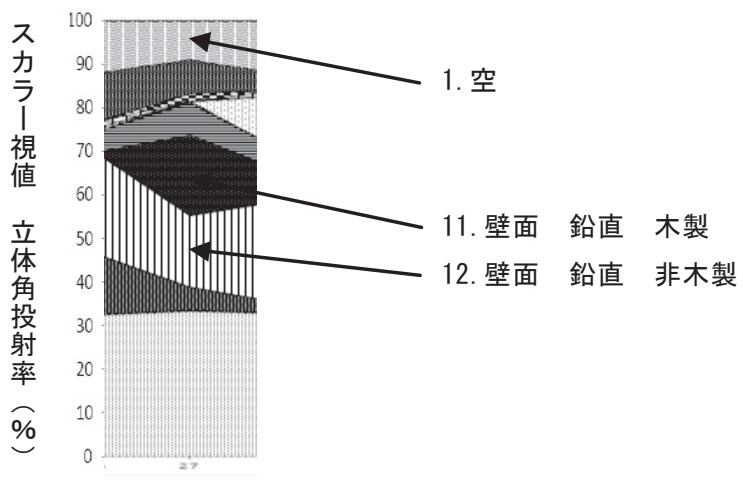

図 18 各観測点 27 のスカラー視指標 


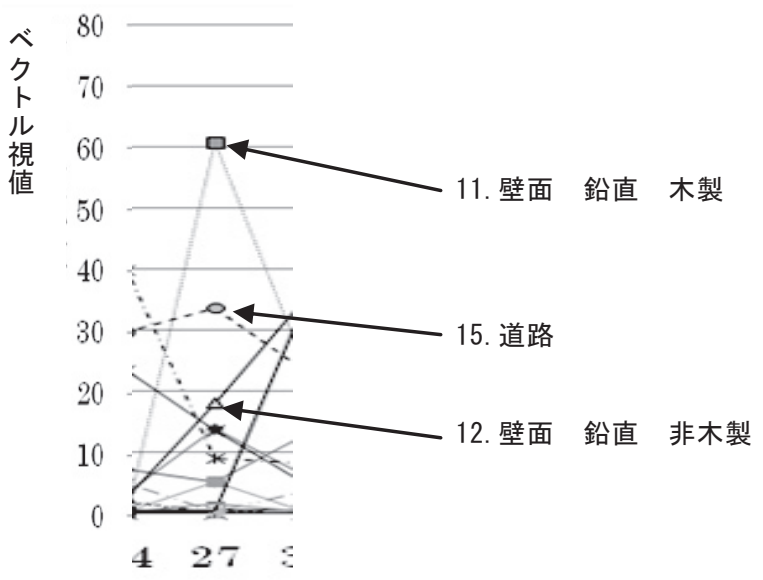

図 19 各観測点 27 のベクトル視指標

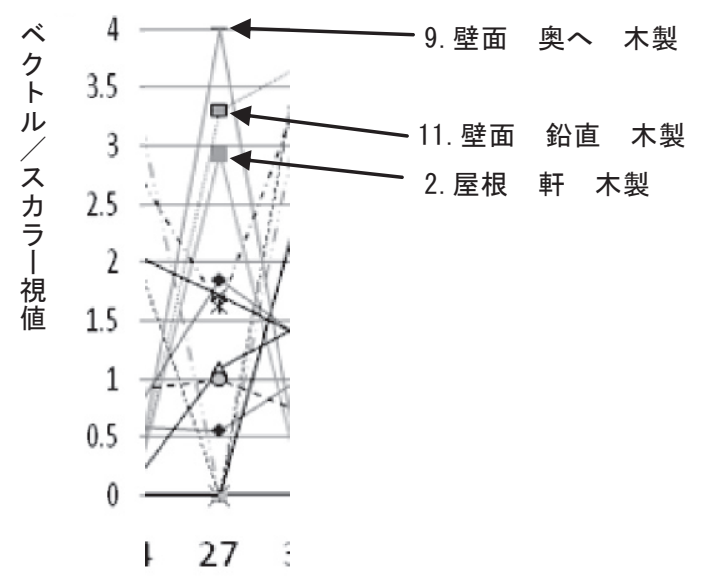

図 20 各観測点 27 のベクトル/スカラー視指標

\section{6. まとめ}

人が景観を見る場合に無意識的に街路を認識する「ながめ」と注 視する「まなざし」による町屋筋の景観を定量的に表現するために、 継続的にまちなみの変化を追い、定量的に指標化する目的で、正射 影魚眼レンズをもちいて立体角投射率をもとめ、「ながめ」に対応 するスカラー視、「まなざし」に対応するベクトル視、総合的にと らえるベクトル/スカラー視比による指標を提案した。スカラー視で は全体的な量の分布を把握し、ベクトル視では指向性を持った要素 を抽出し、ベクトル/スカラー視比では空間の中で突出したものがあ る景観を量的に示すことができた。これらを連成指標として用いる 時、視知覚対象の半球面射影の、平面への投射量が小さい要素であ っても、人が関心を向ける可能性のある要素を抽出し定量化できる 可能性が示された。そして実測から人が無意識的にとらえる「なが め」から連続して、人が関心を寄せる「まなざし」を把握すること ができたと考える。

この指標は、街路を連続的に歩行する状態へ適応するためには、 無意識的な認識の「ながめ」と視線を向けるなどの指向性のある「ま なざし」を連続的に記述することが求められるが、本論文では、研 究の第一段階として、景観を「ながめ」と「まなざし」として定量 的にとらえるための、指標の提示と検討を行うこととし、各点での データを連続データとして用いて評価することを今後の課題とした い。

\section{注}

注 1) 名古屋にみられる路地空間の一種。

\section{参考文献}

1）乾 正雄：建築設計講座 照明と視環,121-126, 理工図書, 1978

2）大野隆造：環境視の概念と環境視情報の記述法:環境視情報の記述法と その応用に関する研究（その 1$)$ ：日本建築学会計画系論文集, $451,85-$ 92,1993

3）若山滋,高瀬啓文,浦木拓也,夏目欣昇：街路景観を構成する色彩・材料 ・ 部位のメッシュアナリシス: 日本建築学会計画系論文集, $615,121-127,2007$

4）益岡了,材野博司:シークェンス景観における歩行者の行動と反応の研究: 日本建築学会計画系論文集,502,163-169,1997

5）川合康央,材野博司街路空間の代替視野画像での注視を促寸空間構成要 素の研究: 京都中心市街地の景観形成過程が夫々異なる街路のシークェン ス：日本建築学会計画系論文集, $542,169-174,2001$

6) 永瀬節治 : 街路歩行者の景観体験における視線方向と景観認識：〈かいま み景観〉概念の適応性に関する研究 日本建築学会計画系論文集, 619 , 109-115, 2007

7）黄泰然,吉澤望,宗方淳,平手小太郎：都市空間における一棟及び多棟建物か ら受ける圧迫感に関する研究:物理指標の対応について: 日本建築学会環境 系論文集, 616, 25-30, 2007

8）守山基樹、門内輝行 : 京都の街並み景観と記号化と記号のネットワークの 記述：街並みの景観における関係性のデザインの分析 その 1 ：日本建築 学会計画系論文集, 652, 1507-1516, 2010

守山基樹、門内輝行 : 街並み景観における類似と差異のパターンの数理生 理学的分析:街並みの景観に関する関係性のデザインの分析 その 2：日 本建築学会計画系論文集, 665, 1275-1284, 2011

9）速水研太、後藤春彦：街路シークエンス景観の定量記述手法に関する研 究：ゆらぎを用いた街路景観特徴記述法の考察及び有効性の検証:日本建築 学会計画系論文集, 502, 155-162, 1997

10）瀬田蕙之、松本直司、青野文晃、河野俊樹、武者利光：ゆらぎ理論に基 づく街路樹と建物の変化が街路景観の乱雑・整然性及び魅力度に与える影 響:中心市街地における乱雑・整然に関する研究 その 3 ：日本建築学会計 画系論文集, 561, 181-188, 2002

11）船越徹、積田洋、清水美佐子: 参道空間の分節と空間構成要素の分析（分 節点分析・物理量分析）一参道空間の研究（その1）：日本建築学会計画系 論文集, 384, 53-61, 1988

12）竹内稔、藤本信義、三橋伸夫 : シークエンス景観と連続シーン景観の評 価構造: 農山村地域における景観評価に関する研究その 1 :日本建築学会計 画系論文集, 475, 119-128, 1995

13）辻大起、岩田伸一郎：二次元地図を用いた都市空間の立体的印象の同定 に関する研究：格子上街区の市街地を対象として：日本建築学会計画系論 文集, 653, 1793-1802, 2010

14）首都大学東京 永田明寬氏によるプログラム http://news-sv.aij/kankyo/s12/Resource/ap/SPCONV/SPCONV.PDF

15）小島武男、中村洋：現代建築環境計画,239 オーム社,1983

16）中村洋ら：視環境評価の指標の簡易測定法に関する検討：日本建築学会 大会学術講演梗概集, $181-182,1981$

17）中村洋ら：新しく試作した六面照度計について：日本建築学会東海支部 研究報告 $25,181-184,1987$

（2012年 1 月 10 日原稿受理， 2012 年 5 月 9 日採用決定） 